\title{
Optimal Drainage Design Under Iraqi Conditions Using DRAINMOD

\author{
Dr.M.R.Hamdi ${ }^{1}$
}

\author{
Dr.A.S.Aldabagh ${ }^{2}$
} \\ Abstract
}

\begin{abstract}
DRAINMOD is a field and watershed scale water management simulation model that has been used to design subsurface drainage systems and characterize drainage and water table control practices in poorly drained soils. DRAINMOD is also used as a research tool to investigate the performance of drainage and sub irrigation systems and their effects on water use, crop response, land treatment of wastewater, and pollutants transport from agricultural fields. The model is based on a water balance in the profile to quantify hydrologic components such as infiltration, subsurface drainage, surface runoff, deep and lateral seepage and evapotranspiration.

The objective of this research is to examine the capability of DRAINMOD to obtain an optimal drainage systems design for Iraqi conditions using the information of Dujailah project. This is done by obtaining the minimum drain depth and maximum spacing that meet the criteria for water table control. The results obtained from DRAINMOD for the drainage systems design show a good agreement with those previously obtained for Dujailah project. Therefore DRAINMOD is a suitable simulation model which can be used to simulate the performance of drainage and water table control systems in Iraq.
\end{abstract}

Keywords :DRAINMOD, optimal drainage design, drainage in Iraq

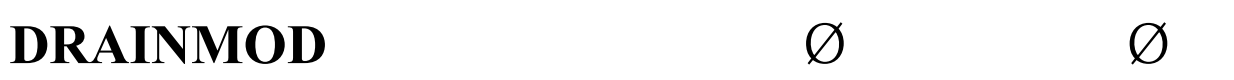

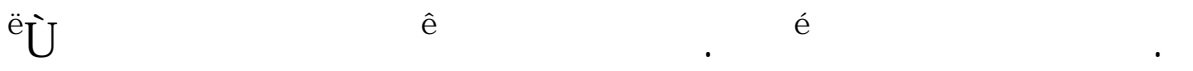

\section{ŭ Ťด}

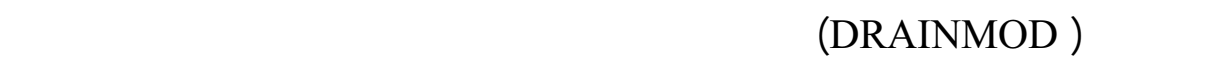

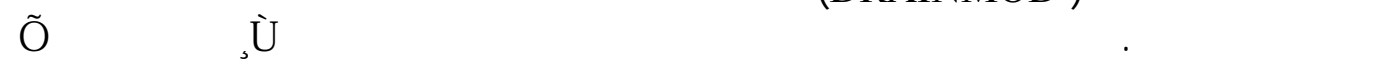
¿ə) E

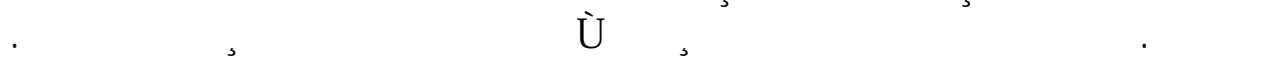

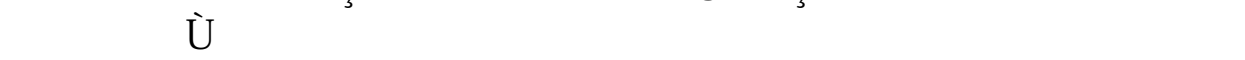

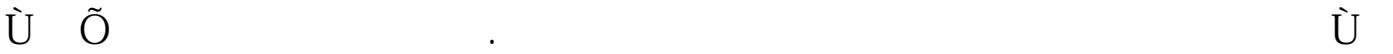

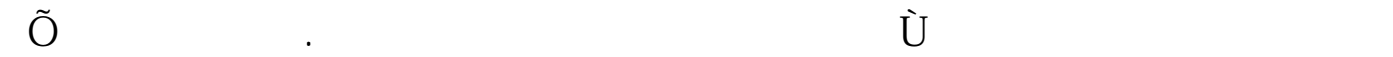

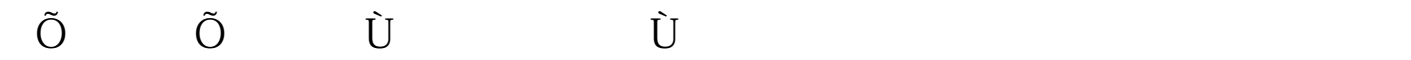
.GU ũt Ŕníddé

${ }^{\mathrm{T}}$ Assistant Professor, College of Natural Resources and Environment, Department of Land Management and Environment, The Hashemite University, Jorden.

${ }^{2}$ Professor, ${ }^{3}$ Lecturer, College of Engineering, University of Mosul, Iraq. 


\section{Introduction}

Improvement of the land quality towards its production potential is a challenging factor facing the world today in winning the war against hunger. This would entail reclaiming the existing low productive and potentially cultivable lands considering the socioeconomic and environmental quality constraints.

The present and potential salt affected land areas of the world amount to about 970 million hectares of which 1.8 million hectares located in Iraq [1]. Thorne and Thorne [2] stated that 122 million hectares, over half the world's irrigated areas, have suffered from drainage and salinity problems. For example, water logging and salinity problems began to be realized since 1927 in Iraq causing thousands of hectares to be taken out of production. Incredibly large investments in drainage of irrigated lands have been made and are being planned. To date, 1.3 million hectares have been artificially drained globally. Country like Iraq has an enormous need for large scale drainage undertakings. However, there has been concern regarding the effectiveness of the installed systems in some areas.

Most of the irrigated areas in the middle and southern Iraq have some sort of artificial drainage systems [3]. Artificial drainage systems are designed for the timely removal of excess water from land to reduce the risk of water damage to crops, soils or field structures. Shallow water tables and high potential evapotranspiration rates complicate salinity management since water may actually move upward into the root zone, carrying with it dissolved salts. Water is then extracted by crops and evaporated, leaving the salts behind on the soil. Shallow water tables also contribute to salinity problem by restricting the downward leaching of salts through the soil profile. At the same time, excessive drainage is undesirable because it reduces soil-water available to growing plants and leaches fertilizers and nutrients, carrying them to receiving streams where they act as pollutants [4]. Installation of subsurface drains is about the only solution available for this situation. Proper spacing and depth of drains maintain the water level at optimum level.

Computer models have been used to relate drainage system performance to design parameters such as drain spacing, depth, etc. Of the drainage models that have been used for arid, irrigated regions include DRAINMOD [5,6,7] and others. DRAINMOD is easier to use and computer execution times are much lower than methods based on numerical twodimensional solutions to the governing flow equations. Besides, the soil property inputs required for the Richards equation are more exact and the solutions more sensitive to errors in those inputs than they are for DRAINMOD. DRAINMOD has been tested and used extensively in the United States as well as several other countries. Field applications include: design and evaluation of drainage systems for agricultural crops, determining wetland hydrology, evaluating wetland restoration techniques that affect wetland hydrology, design and evaluation of drainage systems for on-site and wastewater irrigation, and more recently to evaluate the effects of drainage and water management practices on fate and transport of nitrogen and soil salinity [8]. 
Modifications were made to DRAINMOD to provide the estimates for soil- water flux in the unsaturated zone [9]. These modifications enabled DRAINMOD to be linked to a model to estimate the interactions between irrigation, drainage and salinity in arid regions [10,11]. Additional work has been done linking DRAINMOD with other models including CREAMS [12,13,14,15] and GLEAMS $[16,17,18]$ for simulating erosion, nutrients and pesticide fate and transport on poorly drained soils.

DRAINMOD-N was developed to simulate a simplified version of nitrogen cycle using the water balance calculations of the standard DRAINMOD model. Northcott et al. [19] studied the application of DRAINMOD-N to fields with irregular drainage systems and determined the effective drain spacing.

In the work of $\mathrm{He}$ et al. [20], their results showed that DRAINMOD could be adapted to simulate water table levels in landscapes that do not contain a network of parallel drains.

The purpose of the research reported in this paper is to examine the ability of DRAINMOD for optimal drainage design under Iraqi conditions. The design system is evaluated using the information of Dujailah project.

\section{Experimental Site}

The study was conducted using the information published of $86000 \mathrm{ha}$ site at Dujailah area near Kut, Iraq. The project site is located $30 \mathrm{~km}$ to south-east of Kut at the right bank of the Tigris river at latitudes $32^{\circ} 30^{\prime} \mathrm{N}$ and longitude $47^{\circ}$ E.The climate is arid with long dry summer and about $138 \mathrm{~mm}$ of rainfall in winter with $3389 \mathrm{~mm} / \mathrm{yr}$ of evaporation. The water table is very shallow and may reach $75 \mathrm{~cm}$. This water used to come only from irrigation recharge by deep percolation process [21].The soil is primarily medium textured (sandy clay loam to loam) soil. Soil survey showed that the impermeable layer is at $3.5 \mathrm{~m}$ depth. Although the soil of the project area was stratified and anisotropic, no significant differences between vertical and horizontal hydraulic conductivities were detected. The horizontal hydraulic conductivity ranges between 0.04 and $7 \mathrm{~m} /$ day while the vertical hydraulic conductivity fluctuates between 0.06 and $1.52 \mathrm{~m} /$ day [21].

\section{Processes and Solution Techniques}

DRAINMOD is based on water balance in the soil profile and uses climatological records to simulate the performance of drainage and water table control systems. The model was developed specially for shallow water table soils. Approximate methods are used to quantify the hydrologic components: subsurface drainage, sub irrigation, infiltration, evapotranspiration (ET) and surface runoff [22]. Subsurface drainage is computed using the Hooghoudt equation [23,24,25] and infiltration rates are predicted by Green and Ampt equation [26]. Complex numerical methods are avoided by assuming drainage to equilibrium state for the soil-water distribution above the water table. Inputs to the model include soil properties, weather data, crop variables and site parameters. Soil property inputs include the saturated hydraulic conductivity (by layer), the relationships between drainage volume and water table depth, and information concerning upward flux 
from the water table. The effective root zone depth as a function of time is also needed.

Dujailah project was studied to find the optimal drainage design. The ground water was described to be of class C4-S4 [27]. This bad quality of the ground water put some restriction on the depth of the drains and it was close to the ground level near the irrigation canals. From soil investigations, the impermeable layer was found at a depth of $3.5 \mathrm{~m}$. The lateral saturated hydraulic conductivity was obtained by auger hole tests for each discrete layer to the effective drainage barrier [27]. Nine collector zones with different hydraulic conductivities, which cover the range of drain spacing given in the Dujailah project report, were chosen. The results are shown in Table (5),col.(2-4). Since many different hydraulic conductivity classes were encountered in the field, selection of drain spacing was made in the following way:

- in cases of encountering many hydraulic conductivity classes without a dominant class in the collector zone, drain spacing was adopted according to the lowest hydraulic conductivity values;

- in cases of one dominant class of hydraulic conductivity in the collector zone, drain spacing was defined according to that class; and

- in cases of two characteristic dominant classes of hydraulic conductivity with rather different conductivity, the collector zone was divided into two parts and drain spacings were determined for each part.

In this study,to solve the salinization problem and according to soil investigation, a minimum permissible ground water depth of $1.5 \mathrm{~m}$ and a drain depth of $2.3 \mathrm{~m}$ were used as a design criterion. The drain diameter is $15 \mathrm{~cm}$. Conventional drainage was chosen and, therefore, weir levels were taken equal to the depth to drain. The performance of the drainage system consisting of both surface and subsurface components is analyzed. By conducting simulations for several combinations of surface and subsurface drainage, the best depth-spacing combination of subsurface drains is determined.

A number of input parameters describing the subsurface drainage system are required for each simulation. The desired drain depth is that which meets the criteria for water table control at minimum cost. The initial water table depth was taken equal to half the drain depth[22].

The soil-water characteristic is a measure of how tightly water is held in the soil matrix in saturated state. It is a basic soil property, which is second in importance to only hydraulic conductivity in modeling soil-water movement. Soilwater characteristic values were entered as input data for the top layer of the soil profile along with the corresponding negative pressure heads as shown in Table (1).

Upward flux is the rate of water movement upward from the water table. It is synonymous with the term of capillary movement. Values of upward flux were estimated from data found in previous studies [28]. Table (2) shows volume drained and upward flux corresponding to various water table depths. It was assumed that the seepage is negligible. The drainage coefficient was taken $2 \mathrm{~mm} /$ day [27]. 
The Green-Ampt equation [26] was used to determine the rate of infiltration. Two coefficients (A and B) are used in the equation. Values of $\mathrm{A}$ and $B$ coefficients are derived mathematically from the saturated vertical hydraulic conductivity and the soil-water characteristic [22]. The coefficients A and B along with the depth to water table are shown in Table (3).

Crop rotation was used with winter crops: wheat $50 \%$, linseed $10 \%$, winter pulses $20 \%$, broad beans $20 \%$, and summer crops: cotton $20 \%$, sesame $10 \%$, groundnuts $5 \%$, maize $5 \%$. Net depth of irrigation was determined for each month of the year [21] and given in Table (4).

A MAIN MENU was used to access and edit data in the DRAINMOD input files. The MAIN MENU screen is shown in Table (5).A flowchart,showing each of the screens accessible by the MAIN MENU, is presented in Figure (1) [22].

Table (1) Soil water characteristics for the top layer of the soil profile.

\begin{tabular}{|c|c|}
\hline $\begin{array}{c}\text { Water content } \\
\left(\mathrm{cm}^{3} / \mathrm{cm}^{3}\right)\end{array}$ & $\begin{array}{c}\text { Negative pressure heads } \\
(\mathrm{cm})\end{array}$ \\
\hline 0.49 & 0 \\
\hline 0.488 & 10 \\
\hline 0.482 & 20 \\
\hline 0.475 & 30 \\
\hline 0.470 & 40 \\
\hline 0.41 & 70 \\
\hline 0.37 & 100 \\
\hline 0.31 & 200 \\
\hline 0.29 & 330 \\
\hline 0.26 & 600 \\
\hline 0.23 & 1000 \\
\hline 0.22 & 2000 \\
\hline 0.18 & 4000 \\
\hline
\end{tabular}

Table (2) Values of volume drained per unit area and upward flux corresponding to various water table depths.

\begin{tabular}{|c|c|c|}
\hline Water table depth $(\mathrm{cm})$ & $\begin{array}{c}\text { Volume drained per unit } \\
\text { area }(\mathrm{cm})\end{array}$ & Upward flux $(\mathrm{cm} / \mathrm{hr})$ \\
\hline 0 & 0 & 2 \\
\hline 10 & 0.045 & 1 \\
\hline 20 & 0.2 & 0.8 \\
\hline 30 & 0.44 & 0.25 \\
\hline 40 & 0.83 & 0.12 \\
\hline 70 & 3.5 & 0.05 \\
\hline 100 & 6 & 0.038 \\
\hline 200 & 17 & 0.015 \\
\hline 330 & 34 & 0 \\
\hline 600 & 63 & 0 \\
\hline 1000 & 100 & 0 \\
\hline
\end{tabular}


Table (3) Variation of the Green-Ampt equation coefficients A and B with the depth to water table

\begin{tabular}{|c|c|c|}
\hline $\begin{array}{c}\text { Water table depth } \\
(\mathrm{cm})\end{array}$ & $\mathrm{A}\left(\mathrm{cm}^{2} / \mathrm{hr}\right)$ & $\mathrm{B}(\mathrm{cm} / \mathrm{hr})$ \\
\hline 0 & 0 & 0 \\
\hline 40 & 0.25 & 1.3 \\
\hline 70 & 2.4 & 1.3 \\
\hline 100 & 3.3 & 1.3 \\
\hline 200 & 9 & 1.3 \\
\hline 600 & 25 & 1.3 \\
\hline 1000 & 25 & 1.3 \\
\hline
\end{tabular}

Table (4) Net depth of irrigation ( $\mathrm{mm}$ ) for the crop rotation used in the Dujailah project for each monthof the year[21].

\begin{tabular}{|c|c|c|c|c|c|c|c|c|c|c|c|c|}
\hline Month & 1 & 2 & 3 & 4 & 5 & 6 & 7 & 8 & 9 & 10 & 11 & 12 \\
\hline $\begin{array}{c}\text { Wheat } \\
50 \%\end{array}$ & 22 & 32 & 47 & 58 & 28 & & & & & 16 & 12 & 13 \\
\hline $\begin{array}{c}\text { Linseed } \\
10 \%\end{array}$ & 4 & 5 & 9 & 10 & 7 & & & & & 3 & 2 & 5 \\
\hline $\begin{array}{c}\text { Winter } \\
\text { Pulses } \\
20 \%\end{array}$ & 11 & 12 & 12 & & & & & & 6 & 2 & 7 & 7 \\
\hline $\begin{array}{c}\text { Broad } \\
\text { Beans } \\
20 \% \\
\end{array}$ & 9 & 7 & & & & & & & 6 & 6 & 8 & 8 \\
\hline $\begin{array}{c}\text { Cotton } \\
20 \% \\
\end{array}$ & & & & 10 & 31 & 53 & 69 & 41 & 16 & & & \\
\hline $\begin{array}{c}\text { Sesame } \\
10 \%\end{array}$ & & & & & 1 & 15 & 29 & 25 & 10 & 1 & & \\
\hline $\begin{array}{c}\text { Groundn } \\
\text { uts } 5 \%\end{array}$ & & & & 5 & 10 & 15 & 14 & 7 & 1 & & & \\
\hline $\begin{array}{c}\text { Maize } 5 \\
\%\end{array}$ & & & 1 & 7 & 15 & 16 & 5 & & & & & \\
\hline In (ave) & 46 & 56 & 69 & 90 & 92 & 99 & 117 & 73 & 39 & 28 & 29 & 33 \\
\hline
\end{tabular}

* In(ave) -total net depth of irrigation 
Hamdi : Optimal Drainage Design Under Iraqi Conditions Using DRAINMOD

Table (5)The MAIN MENU for editing DRAINMOD input data.

\begin{tabular}{|c|l|}
\hline \multirow{2}{*}{ Topic No. } & \multicolumn{1}{|c|}{ EDIT MENU } \\
\cline { 2 - 2 } & Select Topic to Edit \\
\hline 0 & Edit All Screens \\
\hline 1 & General Information \\
\hline 2 & Weather Inputs \\
\hline 3 & Drainage Design Parameters \\
\hline 4 & Lateral Saturated Hydraulic Conductivity \\
\hline 5 & Soils Data \\
\hline 6 & Trafficability Inputs \\
\hline 7 & General Crop Inputs \\
\hline
\end{tabular}

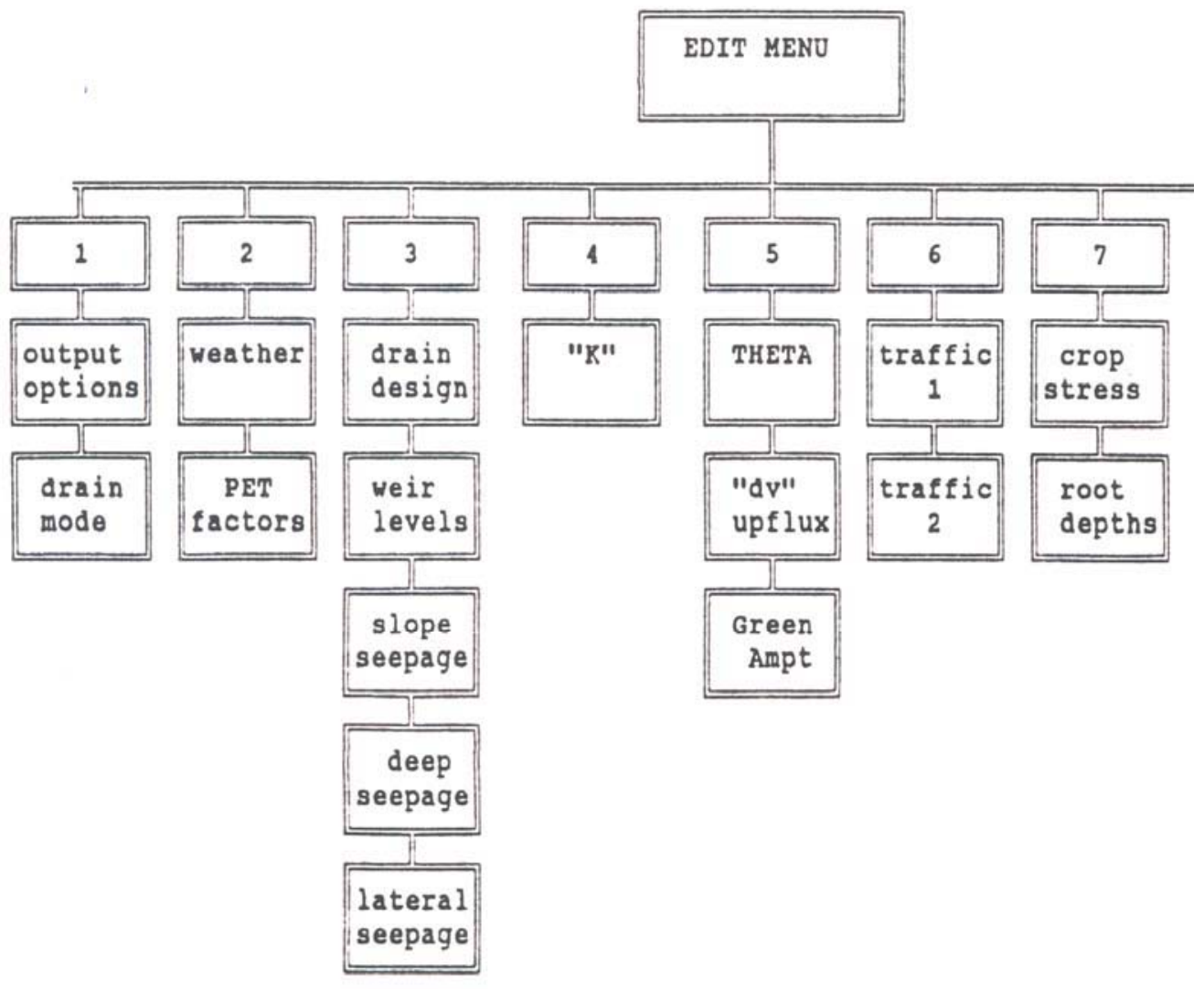

Figure (1) Flowchart showing screens accessible from the MAIN MENU.

Results and Discussion 


\section{Results and Discussion}

In order to check the capability of DRAINMOD in the design of drainage system for Dujailah project, the same nine collector zones with different hydraulic conductivities were chosen. Table (6), col. (7) shows the results obtained from DRAINMOD for these zones. In the Dujailah project report [27] the final drain spacing values were rounded off to the nearest figure divisible by $15 \mathrm{~m}$ in order to be in agreement with irrigation plot widths. Results are shown in Table (6), col. (5). In order to check the accuracy of these results, Alkheero [29] used the modified Hooghoudt-Ernst equation to calculate the drain spacing. The results are given in Table (6),col.(6). The final results of DRAINMOD were also rounded off to the nearest figure divisible by $15 \mathrm{~m}$ as shown in Table (6),col.(8).

Figure (2) shows the water table hydrograph during a year for the designed collector drains. The figure shows the fluctuations of water table for the collector zones with different drain spacings that maintain the optimum water table depth at $1.5 \mathrm{~m}$.

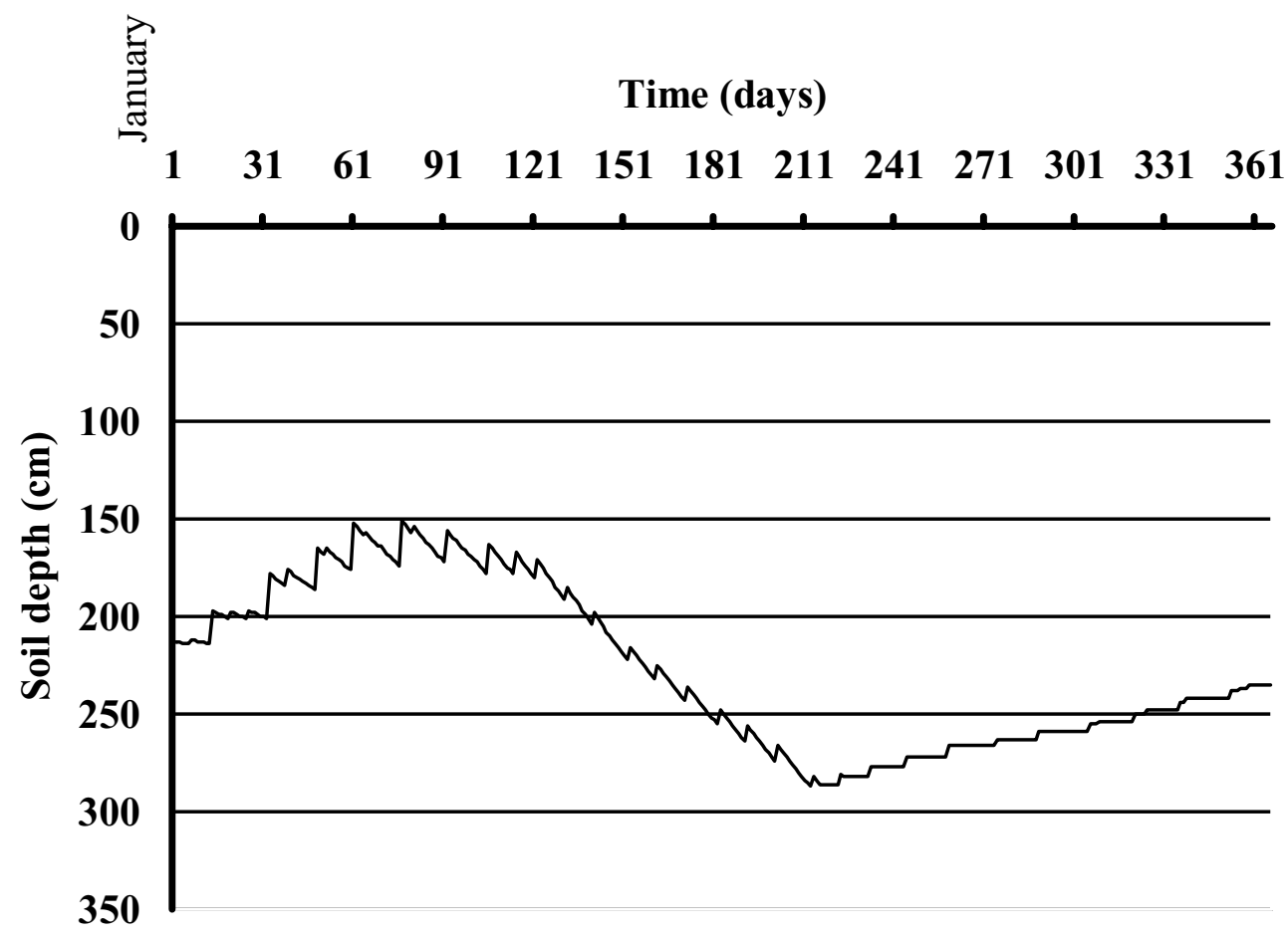

Figure(2)Water table hydrograph for the collector zones in the Dujailah project. 
Hamdi : Optimal Drainage Design Under Iraqi Conditions Using DRAINMOD

Table (6) Drain spacings given in the Dujailah project report [27] and those calculated by Alkheero [29] and obtained from DRAINMOD.

\begin{tabular}{|c|c|c|c|c|c|c|c|}
\hline \multirow[t]{2}{*}{$\begin{array}{c}\text { Collector } \\
\text { zone }\end{array}$} & \multicolumn{3}{|c|}{$\begin{array}{l}\text { Hydraulic conductivity in } \\
\text { the collector zone } \\
(\mathrm{m} / \text { day })\end{array}$} & \multicolumn{4}{|c|}{ Drain spacings $(\mathrm{m})$} \\
\hline & $\mathrm{K}_{1}$ & $\mathrm{~K}_{2}$ & $\mathrm{~K}_{3}$ & $\begin{array}{l}\text { Dujailah } \\
\text { report } \\
{[27]}\end{array}$ & $\begin{array}{c}\text { Alkheero } \\
\text { [29] }\end{array}$ & $\overline{\mathrm{DRA}}$ & $\overline{M O D}$ \\
\hline 1 & 2 & 3 & 4 & 5 & 6 & 7 & 8 \\
\hline \multirow[t]{2}{*}{ D-3-2-5 } & 0.75 & 1.5 & 0.15 & \multirow[t]{2}{*}{45} & 78 & 75 & \multirow[t]{2}{*}{45} \\
\hline & 0.75 & 0.25 & 0.15 & & 53 & 48 & \\
\hline \multirow{3}{*}{ D-4-2-2 } & 0.75 & 1.5 & 0.31 & \multirow{3}{*}{60} & 78 & 75 & \multirow{3}{*}{60} \\
\hline & 0.75 & 0.75 & 0.31 & & 64 & 60 & \\
\hline & 0.75 & 3.0 & 0.31 & & 99 & 99 & \\
\hline \multirow{4}{*}{ D-3-0-6 } & 1.5 & 1.5 & 1.0 & \multirow{4}{*}{75} & 93 & 90 & \multirow{4}{*}{75} \\
\hline & 1.5 & 3.0 & 1.0 & & 110 & 110 & \\
\hline & 0.75 & 1.5 & 1.0 & & 78 & 75 & \\
\hline & 3.0 & 3.0 & 1.0 & & 133 & 125 & \\
\hline D-3-1-10 & 0.75 & 1.5 & 0.15 & 75 & 78 & 75 & 75 \\
\hline \multirow[t]{2}{*}{ D-2-16-0 } & 1.5 & 1.5 & 0.15 & \multirow[t]{2}{*}{90} & 93 & 90 & \multirow[t]{2}{*}{90} \\
\hline & 1.5 & 3.0 & 0.15 & & 110 & 110 & \\
\hline \multirow{5}{*}{ D-3-1-9 } & 0.75 & 1.5 & 0.12 & \multirow{5}{*}{45} & 78 & 75 & \multirow{5}{*}{45} \\
\hline & 0.25 & 0.25 & 0.12 & & 35 & 33 & \\
\hline & 0.75 & 0.25 & 0.12 & & 53 & 48 & \\
\hline & 0.75 & 0.75 & 0.12 & & 64 & 60 & \\
\hline & 0.25 & 0.75 & 0.12 & & 48 & 49 & \\
\hline \multirow{5}{*}{ D-3-1-2 } & 0.75 & 1.5 & 1.23 & \multirow{5}{*}{60} & 78 & 75 & \multirow{5}{*}{60} \\
\hline & 0.75 & 0.25 & 1.23 & & 53 & 48 & \\
\hline & 0.75 & 0.75 & 1.23 & & 64 & 60 & \\
\hline & 3.0 & 3.0 & 1.23 & & 133 & 125 & \\
\hline & 1.5 & 3.0 & 1.23 & & 110 & 110 & \\
\hline \multirow[t]{2}{*}{ D-3-0-11 } & 1.5 & 1.5 & 0.15 & \multirow[t]{2}{*}{105} & 93 & 90 & 90 \\
\hline & 3.0 & 3.0 & 0.15 & & 133 & 125 & 120 \\
\hline D-2-0-24 & 3.0 & 3.0 & 0.52 & 120 & 133 & 125 & 120 \\
\hline
\end{tabular}

$\mathrm{K}_{1--}$ Lateral hydraulic conductivity of layer $(0.0-2.5) \mathrm{m}$

$\mathrm{K}_{2 \text {-- Lateral hydraulic conductivity of layer }(2.5-3.5) \mathrm{m}}$

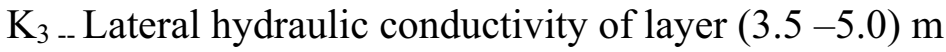


The results given in Table (6),col.(7,8) show different drain spacings corresponding to the different hydraulic conductivity classes which were encountered in the field. The drain spacings are approximately the same as those given in the Dujailah project report [27] and those obtained by Alkheero [29].

For the collector zones (D-3-2-5), (D-4-2-2), (D-3-0-6) and (D-2-16-0), the drain spacings shown in Table (6),col.(8) were adopted according to the lowest hydraulic conductivity values since many hydraulic conductivity classes without a dominant class were encountered in the collector zone. In the collector zones (D-3-1-10) and (D-2-0-24) one dominant class of hydraulic conductivity was encountered, so the drain spacing was defined according to that class. For the collector zones (D-3-1-9) and (D-3-1-2), the lowest hydraulic conductivity values, that give drain spacing of $33 \mathrm{~m}$ and $48 \mathrm{~m}$ respectively, were neglected because they were not dominant, and the drain spacings were adopted according to the next lowest hydraulic conductivity. In the collector zone (D-3-0-11) two characteristic dominant classes of hydraulic conductivity were encountered, so the collector zone was divided into two parts and the drain spacings were determined for each part.

The results obtained from DRAINMOD for optimal drainage design show good agreement with those exist in the Dujailah project. This emphasis the capability of DRAINMOD to obtain the best drainage design under Iraqi conditions .

DRAINMOD is indispensable for drainage design of large projects and useful if properly applied when adequately address appropriate objectives, and when the model include proper representation of the physical conditions of the drainage site. Future research will be addressed to check the validity of DRAINMOD to simulate and describe some hydrologic variables. 


\section{References}

1. FAO. Salinity. Irrigation and Drainage Paper 7. Rome.(1971).

2. Thorne, D.W. and M.D. Thorne. Soil, water and crop production. AVI Publishing Company, Inc. Westport, Connecticut. 358 p.(1979).

3. Dilleman P.J. Reclamation of salt-affected soils in Iraq. ILLRI Publication II, Wagenigen, the Netherlands. (1963).

4. Skaggs. R.W. Modeling Plant and Soil Systems. Agronomy Monograph No.31.USA. (1991).

5. Skaggs, R.W. Evaluation of water table control systems using a water management model. Proceedings, Third National Drainage Symposium, ASAE, St. Joseph, MI, p 61-68. (1976).

6. Durnford, D.S., T.H. Podmore, and E.V. Richardson. Optimal Drain design for arid, in irrigated areas. Transactions ASAE 27(4):1100 - 1105.(1982).

7. Gates', T. K. and M. E. Grismer. Stochastic optimal management of perched saline aquifers in irrigated regions. Proceedings of the International Conference on Groundwater Contamination: Use of the Decision Making. International Groundwater Modeling Center, Amsterdam, Holland.(1987b).

8. Westra John V., K. William Easter, and Kent D. Olson. Targeting Nonpoint Source Pollution Control. JAWRA, Volume 38, No. 2, pp. 493-505. (2002).

9. Skaggs, R.W., Karnoven, T. and Kandil, H. Predicting Soil-Water Fluxes in Drained Lands. ASAE Paper No. 91-2090 St. Joseph, MI. (1991).

10. Kandil, H.M. Skaggs, R.W., Dayem, S.A. and Aiad, Y. DRAINMOD-S: water Management Model for Irrigated Arid Lands, Crop Yield and Application. Irrigation and Drainage Systems. Vol. 9(3): 239-258. (1995).

11. Merz, R.D. and Skaggs, R.W. Application of DRAINMOD-S to Determine Drainage Design Criteria for Irrigated Semi-Arid Lands. In: Drainage in the 21st Century: Food Production and Environment. Proc. of the Seventh International Drainage Symposium Ed. Larry C. Brown. March 8-10,1998. ASAE. PP.347-354. (1998).

12. Knisel, W.G. (Ed.) CREAMS: A field-scale Model for Chemicals, Runoff, and Erosion from Agriculture Management Systems U.S. Department of Agriculture, Science and Education Administration, Conservation Research Report No.26. Washington, DC.643 PP. (1980).

13. Parsons, J.E. and Skaggs, R.W. Water Quality Modeling with DRAINMOD and CREAMS. ASAE Paper No.88-2569. 17pp. (1988).

14. Saleh, A. R., R. L. Bengston and J. L. Fouss. Performance of the DRAINMOD-CREAMS model with an incorporated nutrient submodel. Trans. ASAE. Vol. 37(4):1109-1114.(1994).

15. Wright, J.A., Shirmohammadi, A., Magett, W.L., Fouss, J.L., Bengston, R.L. and Parsons, J.E. Water Table Management Practice Effects on Water Quality. Trans. ASAE. Vol. 35(3): 823-831.(1992).

16. Leonard, R.A., Knisel, W.A. and Still, D.A. GLEAMS: Groundwater Loading Effects of Agricultural Management Systems. Trans. ASAE. 30(5): 14031418. (1987). 
17. Kinsel, W.G. (Ed). GLEAMS: Groundwater Loading Effects of Agricultural Management Systems. Version 2.10.UGS-CPES-BAED Publication No.5. Coastal Plain Exp. Sta., BAE Dept., Tifton, GA. 259pp. (1993).

18. Thooko, L.W., Rudra, R.P., Dickinson, W.T., Patni, N.K. and Wall, G.J. Modeling Pesticide Transport in Subsurface Drained Soils. Trans. ASAE. Vol.37 (4): 1175-1181. (1994).

19. Northcott WJ, Cooke R.A. Walker S.E. Mitchell J.K. And Hirschi M.C. Application of DRAINMOD-N to fields with Irregular Drainage Systems Source. Trans. ASAE.44 (2): 241-249, (2001).

20. He, X., Vepraskas, M.J., Skaggs, R.W. and Lindbo, D.L. Adapting a Drainage Model to Simulate Water Table Levels in Coastal Plain Soils. Soil Science Society of America Journal 66(5): 1722-1731 (2002).

21. Pencol Engineering Consultants. Design Manual for Irrigation and Drainage. State Organization for Land Reclamation, Ministry of Irrigation, Baghdad, Iraq.(1983).

22. Workman, S. R., J. E. Parsons, G. M. Chescheir, R. W. Skaggs and J. F. Rice. DRAINMOD User's Guide. NRCS, Washington, DC and NC State Univ. Raleigh, NC. 133 pp.USA (1994).

23. Kirkham, D. Theory of Land Drainage, In, Drainage of Agricultural Lands, Agronomy Monograph No.7. American Society of Agronomy, Madison, Wisconsin. (1957).

24. Luthin, James, N. Drainage Engineering. John Wiley and Sons, Inc., New York.250 pp. (1978).

25. Ernst, L.F. Formula for Groundwater Flow in Areas with Sub irrigation by Means of Open Conduits with a Raised Water Level. Misc Reprint 178, Institute for Land and Water Management Research, Wageningen. The Netherlands.32pp. (1975).

26. Green, W.H. and Ampt, G. Studies of Soil Physics, part 1. The Flow of Air and Water Through Soils. J. Agricultural Science 4: 1-24 (1911).

27. Agricultural Combine "Beograd"(PKB). Dujailah Agroindustrial Complex Irrigation and Drainage System. Vols. 1,1.1 and 1.2. Ministry of Agriculture and Agrarian Reform, Iraq. (1977).

28. Al-Jubouri, K.A. Evaporation from Soil Surface in Presence of Shallow Water Tables. M.sc Thesis. University of Mosul, Iraq. (1987).

29. Alkheero, N.A. Evaluation of Depth and Spacing of Field Drains in Iraq. M.sc Thesis. University of Mosul, Iraq. (1983). 